\title{
Coronavirus (COVID-19), Coagulation, and Exercise: Interactions That May Influence Health Outcomes
}

Emma Kate Zadow, BSc (Hons.), PhD ${ }^{1}$ Daniel William Taylor Wundersitz, BSc (Hons.), PhD ${ }^{1}$

Diane Louise Hughes, BSc (Hons.), PhD ${ }^{1,2}$ Murray John Adams, BSc (Hons.), PhD ${ }^{3}$

Michael Ian Charles Kingsley, BPhEd, MSc, PhD ${ }^{1,4}$ Hilary Anne Blacklock, MB ChB ${ }^{5}$

Sam Shi Xuan Wu, BSc, MSc, PhD ${ }^{6}$ Amanda Clare Benson, BEd(Phys. Ed), MSc, PhD 6

Frédéric Dutheil, MD, $\mathrm{PhD}^{7}$ Brett Ashley Gordon, BAppSc, MAppSc, $\mathrm{PhD}^{1}$

${ }^{1}$ Holsworth Research Initiative, La Trobe Rural Health School, La Trobe University, Bendigo, Victoria, Australia

2 Department of Pharmacy and Biomedical Sciences, School of Molecular Sciences, La Trobe University, Bendigo, Victoria, Australia

${ }^{3}$ College of Science, Health, Engineering and Education, Murdoch

University, Murdoch, Western Australia, Australia

${ }^{4}$ Department of Exercise Sciences, University of Auckland,

Auckland, New Zealand

${ }^{5}$ Department of Haematology, Middlemore Hospital, Auckland,

New Zealand

${ }^{6}$ Department of Health and Medical Sciences, Swinburne University of Technology, Hawthorn, Victoria, Australia

${ }^{7}$ Université Clermont Auvergne, CNRS, LaPSCo, Physiological and Psychosocial Stress, CHU Clermont-Ferrand, University Hospital of Clermont-Ferrand, Preventive and Occupational Medicine, Witty Fit, Clermont-Ferrand, France

Semin Thromb Hemost 2020;46:807-814.

Address for correspondence Emma Kate Zadow, BSc (Hons), PhD, Holsworth Research Initiative, La Trobe Rural Health School, La Trobe University, Edwards Road, Flora Hill, Bendigo, Victoria 3550, Australia (e-mail: e.zadow@latrobe.edu.au).

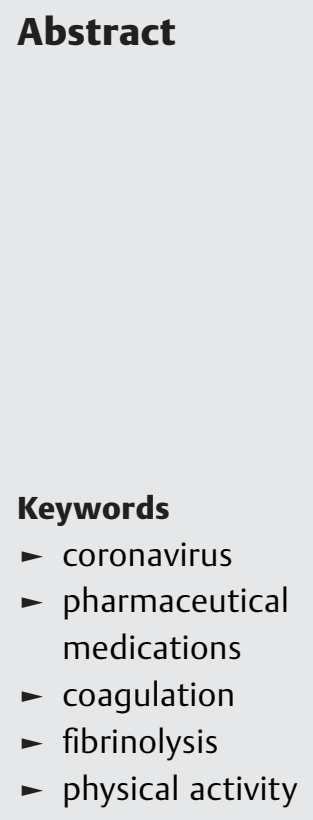

The proinflammatory cytokine storm associated with coronavirus disease 2019 (COVID-19) negatively affects the hematological system, leading to coagulation activation and endothelial dysfunction and thereby increasing the risk of venous and arterial thrombosis. Coagulopathy has been reported as associated with mortality in people with COVID-19 and is partially reflected by enhanced D-dimer levels. Poor vascular health, which is associated with the cardiometabolic health conditions frequently reported in people with severer forms of COVID-19, might exacerbate the risk of coagulopathy and mortality. Sedentary lifestyles might also contribute to the development of coagulopathy, and physical activity participation has been inherently lowered due to at-home regulations established to slow the spread of this highly infectious disease. It is possible that COVID-19, coagulation, and reduced physical activity may contribute to generate a "perfect storm," where each fuels the other and potentially increases mortality risk. Several pharmaceutical agents are being explored to treat COVID-19, but potential negative consequences are associated with their use. Exercise is known to mitigate many of the identified side effects from the pharmaceutical agents being trialled but has not yet been considered as part of management for COVID-19. From the limited available evidence in people with cardiometabolic health published online September 3, 2020
Issue Theme Maintaining Hemostasis and Preventing Thrombosis in COVID-19 -Part I; Guest Editors: Emmanuel J. Favaloro, PhD, FFSc (RCPA), and Giuseppi Lippi, MD.
Copyright $\odot 2020$ by Thieme Medical Publishers, Inc., 333 Seventh Avenue, New York, NY 10001, USA. Tel: +1(212) 760-0888.
DOI https://doi.org/ $10.1055 / \mathrm{s}-0040-1715094$. ISSN 0094-6176. 
conditions, low- to moderate-intensity exercise might have the potential to positively influence biochemical markers of coagulopathy, whereas high-intensity exercise is likely to increase thrombotic risk. Therefore, low- to moderate-intensity exercise could be an adjuvant therapy for people with mild-to-moderate COVID-19 and reduce the risk of developing severe symptoms of illness that are associated with enhanced mortality.

Since the first reported case of coronavirus disease 2019 (COVID-19) in 2019, ${ }^{1}$ as caused by the severe acute respiratory syndrome coronavirus 2 (SARS-CoV-2), a global pandemic has ensued and infection rates have increased exponentially. ${ }^{2}$ At the time of writing, this highly contagious virus had infected more than 6 million people globally, resulted in more than 400,000 deaths, $^{3}$ and has been forecast to cost the global economy more than two trillion U.S. dollars in 2020 alone. ${ }^{4}$ People with COVID-19 can present with mild symptoms, which may progress to severe disease and affect multiple organs beyond the lungs, including the hematological systems. ${ }^{5-10}$ Such COVID-19-related effects can contribute to an increased risk of venous and arterial thrombosis. ${ }^{11,12}$ Although there remains an urgent need for clinical biomarkers to predict disease severity, ${ }^{13}$ hematological impacts including increased D-dimer, fibrinogen, von Willebrand factor, and factor VIII (FVIII) levels have been associated with the occurrence of coagulopathy in COVID-19. ${ }^{14}$ Many pharmacological agents have been proposed for treating COVID-19, ${ }^{15,16}$ although exercise has yet to be considered as part of treatment options. Therefore, this review explores how exercise could be prescribed to influence coagulopathy and how it might interact with pharmaceutical medications being used in people with COVID-19.

\section{COVID-19 and Hemostasis}

Hemostasis is the physiological process that maintains the balance between excessive bleeding and clotting to achieve normal blood circulation. ${ }^{11,17-19}$ To maintain normal circulation, a dynamic equilibrium between activators and inhibitors of hemostasis occurs, including (1) the vascular system, (2) blood platelets, (3) the coagulation system, (4) the physiological inhibitors of coagulation, and (5) the fibrinolytic system. ${ }^{11,20,21}$

Blood platelets, typically the first responders when damage to the vascular endothelium occurs, are known to directly interact with different viruses. ${ }^{22}$ However, it remains unclear how platelets interact with SARS-CoV-2. ${ }^{23}$ Hypoxia, a common clinical feature of COVID-19, ${ }^{1,24}$ increases thrombus under systemic or local hypoxic conditions. ${ }^{25}$ Hypoxia-inducible transcription factors directly activate platelets but also increases the inflammatory response. ${ }^{26,27}$ In healthy individuals, fibrinolysis is regulated by tissue plasminogen activator (t-PA) and plasminogen activator inhibitor-1 (PAI-1).20,28 COVID-19 prompts immune cells to release a cytokine storm that ramps up inflammation, platelet activation, endothelial dysfunction, hypoxia, and stasis of blood flow as a result of prolonged immobility. ${ }^{24,29,30}$ The resulting coagulation abnormalities are recognized as "COVID-19-associated coagulopathy." 10

\section{COVID-19 and Coagulopathy}

It has been reported that up to $68 \%$ of people diagnosed with COVID-19 and needing intensive care have preexisting comorbidities known to affect the vascular system, including hypertension, cardiovascular disease, hypercholesterolemia, and diabetes. ${ }^{31}$ These conditions typically stem from, or contribute to, the metabolic syndrome, which is associated with increased amounts of visceral adipose tissue. This tissue is known to secrete several cytokines that are implicated in the inflammatory cascade, leading to a state of low-grade inflammation. ${ }^{32}$ Reports on clinical characteristics of COVID19 intensive care patients include elevated cytokine levels such as interleukin (IL)-2, IL-7, IL-10, granulocyte colonystimulating factor, interferon gamma-induced protein 10 (IP-10), monocyte chemoattractant protein-1 (MCP1), macrophage inflammatory protein-1 $\alpha($ MIP1A), and tumor necrosis factor- $\alpha$ (TNF $\alpha)^{1}$ Activation of these cytokines can result in an inflammatory cascade, leading to coagulation activation and endothelial dysfunction. ${ }^{33,34}$

Elevated levels of proinflammatory cytokines might partially explain the large number of COVID-19 infected individuals presenting with coagulopathy, ${ }^{35}$ in particular elevated Ddimers, ${ }^{1,29,30}$ fibrinogen degradation products (FDPs), ${ }^{35}$ and abnormal activated partial thromboplastin time. ${ }^{1,29}$ Elevations in these coagulopathy parameters and impaired fibrinolysis are significantly related to poor prognosis in COVID-19. ${ }^{28,30,35}$ For example, Zhou et al ${ }^{36}$ reported that $68 \%$ of patients presenting with COVID-19 had increased activation of coagulation as indicated by elevated D-dimer concentration at presentation $\left(>500 \mathrm{ng} / \mathrm{mL}\right.$ ). Most importantly, Zhou et $\mathrm{al}^{36}$ reported that Ddimer concentrations $>1,000 \mathrm{ng} / \mathrm{mL}$ were associated with an eightfold increased odds of fatal outcome, suggesting coagulopathy to be a predictor of mortality risk in individuals with COVID-19. ${ }^{35}$

D-dimer is a widely used clinical biomarker of endogenous fibrin clot formation ${ }^{37-42}$ and a well-recognized laboratory marker of hypercoagulability (coagulation activation). ${ }^{43-45}$ Elevated D-dimer levels in people with COVID-19 are associated with a higher risk of intensive care unit admission or death. ${ }^{46}$ The mortality risk associated with higher levels of D-dimer is particularly evident in older people and those with cardiometabolic comorbidities. ${ }^{30}$ In addition to elevated D-dimer levels, Tang et $\mathrm{al}^{35}$ reported significantly higher levels of FDPs and 
prolonged prothrombin time (PT) in COVID-19 nonsurvivors compared with those who survived. Therefore, it can be suggested that these conventional parameters of coagulation are significantly associated with overall prognosis.

\section{Physical Activity and Risk for Coagulopathy}

A common behavioral feature, and risk factor, for the comorbidities associated with COVID-19 is insufficient physical activity. ${ }^{47}$ A diagnosis of COVID-19, whether mild or severe symptoms occur, is likely to reduce physical activity even further in those required to isolate in the home environment or be bedbound in a hospital setting. ${ }^{48}$ While under instructions to self-isolate indoors to slow the outbreak of COVID-19, data obtained by smartwatches have demonstrated that weekly physical activity has decreased by $9 \%$ to $48 \% .{ }^{49,50}$ This reduction in physical activity is frequently associated with venous thromboembolism, ${ }^{51}$ which typically consists of pulmonary embolism or deep vein thrombosis. ${ }^{52,53}$ These major clinical problems negatively alter blood coagulability and have potential life-threatening consequences, such as acute cardiac injury and/or sudden death. ${ }^{35,54}$ Therefore, it may be that COVID-19, coagulation, and reduced physical activity contribute to generate a "perfect storm," ${ }^{55}$ where each fuels the other and potentially increases mortality risk. Physical activity can induce many health benefits ${ }^{56,57}$ and can positively modify coagulation markers in healthy populations. ${ }^{58,59}$ High cardiorespiratory fitness has been suggested to offer some protection against the deleterious effects of COVID-1960 and consequently it is important to safely participate in physical activity during this pandemic. ${ }^{61}$ Therefore, early intervention through physical activity or exercise might mitigate negative health consequences and reduce mortality risk in people with mild or moderate COVID-19. However, at this point, it is not clear if, or how, physical activity or exercise can be used as part of the overall treatment process for coagulopathy associated with COVID-19.

\section{Exercise and Hemostasis}

Exercise (planned physical activity completed specifically for the purpose of improving health and fitness) has been demonstrated to have considerable effects on hemostasis by positively modifying markers of coagulation and fibrinolytic response in apparently healthy populations. ${ }^{58,59,62}$ Low- to moderate-intensity exercise is likely to reduce the risk of coagulopathy; however, acute bouts of high-intensity exercise may act as a potential trigger for increased thrombotic risk due to an increase in venous blood flow, blood viscosity, and laminar shear stress, activating the coagulation system. ${ }^{63,64}$ Nonetheless, the influence of acute bouts of exercise on coagulation and fibrinolysis have often produced conflicting data due to various factors including varying study protocols and exercise modes. ${ }^{62,65-69}$ It is evident that exercise intensity plays an influential role in shifting the equilibrium between coagulation and fibrinolysis, with strenuous (high-intensity) exercise consistently demonstrated to increase hemostatic activation as opposed to low- to moderate-intensity exercise. ${ }^{63,64,70-73}$
For apparently healthy individuals, exercise completed at a higher intensity appears to increase clot degradation, probably in response to coagulation activity. This is evidenced by an increase in overall fibrinolytic activity when cycling at $70 \% \mathrm{VO}_{2}$ max compared with $40 \% \mathrm{VO}_{2} \max ^{74}$ but also an approximately $50 \%$ increase in t-PA activity when cycling at $80 \% \mathrm{VO}_{2} \max$ compared with $50 \% \mathrm{VO}_{2}$ max. ${ }^{62}$ Furthermore, Menzel and Hilberg $^{75}$ observed increased thrombin-antithrombin complexes when cycling at $100 \%$ but not at $80 \%$ individual anaerobic threshold. These findings indicate that exercise intensity is an important contributor to thrombin generation through activation of both the coagulation and fibrinolytic systems, albeit in a healthy population, ${ }^{76}$ and it is clear that to minimize the risk of coagulopathy, moderate- to high-intensity exercise should be avoided by untrained, inappropriately trained, or sedentary individuals. ${ }^{77-79}$ Despite this, there remains an opportunity to explore the use of exercise as an adjuvant therapeutic tool in the management and prevention of COVID-19-associated coagulopathy.

Separate to acute responses to exercise, individuals who are regularly physically active possess a "thromboprotective element," whereas individuals who are not regularly active or those with a preexisting medical condition have attenuated fibrinolytic responses in combination with exaggerated changes in procoagulant and platelet variables. ${ }^{65,80-83}$ When investigating coagulation and fibrinolytic responses in relation to exercise in physically inactive individuals and those with varying medical conditions (i.e., peripheral arterial disease, metabolic syndrome, hemiparetic strokes, and hypertension), exercise intensity varied between $50 \%$ and $70 \%$ $\mathrm{VO}_{2}$ max..$^{62,84-87}$ Exercise performed at $50 \% \mathrm{VO}_{2}$ max increased fibrinolytic activity in both active and inactive apparently healthy males, but larger increases in t-PA were observed only in physically inactive males. ${ }^{62}$ In sedentary males with metabolic syndrome, exercise at $70 \% \mathrm{VO}_{2}$ max reduced fibrinolytic activity and these individuals remained hypofibrinolytic compared with non-obese sedentary males. ${ }^{86}$ In middle-aged females with previous myocardial infarction, Eriksson-Berg et $\mathrm{al}^{68}$ demonstrated increased fibrinolytic activity following exercise at 50\% maximal work capacity, whereas markers of coagulation activation remained undisrupted. Low- to moderate-intensity exercise in people with varying medical conditions increases fibrinolytic activity, as evidenced by elevated t-PA concentrations, which may persist up to 1 hour postexercise. ${ }^{84,85,87}$ Therefore, even for individuals with existing cardiometabolic health conditions associated with worse COVID-19 outcomes, lower intensity exercise may have thromboprotective effects. ${ }^{63}$ It is then possible that low- to moderate-intensity exercise may increase acute fibrinolytic activity and reduce COVID-19-associated blood clot formation. However, to date, no studies have investigated how exercise might impact the hemostatic profile within this population.

\section{COVID-19, Pharmaceutical Agents, and Exercise}

No universal pharmaceutical treatment for COVID-19 is as yet available, although multiple therapeutic strategies are 
being attempted and trialled. ${ }^{15,16,88-91}$ These relate to pharmaceutical agents that (1) block viral entry to host cells through the prevention of attachment or fusion, or removal of virus by immune cells, or the use of hyperimmune plasma, (2) block viral replication and survival in host cells through viral protease inhibition or viral nucleic acid and protein synthesis inhibition, (3) dampen the exaggerated immune response through corticosteroids, cytokine blockade, or intravenous immunoglobulin, and/or (4) inhibit the abnormal prothrombotic response by anticoagulants. ${ }^{88,92}$

Due to the broad range of pharmaceutical agents being trialed for COVID-19, and the apparent impact of the virus on hematological parameters that are associated with poor prognosis and mortality, ${ }^{13}$ it is critical to examine the possible pharmaceutical agent interactions with exercise. - Table 1 indicates the broad class of pharmaceutical agents being trialled for COVID-19, ${ }^{15,16}$ potential consequences associated with their use, and implications for exercise.
Anti-inflammatory agents have been used to minimize systemic inflammation and augment hemostasis. However, some anti-inflammatory agents inhibit the receptor for IL- $6,{ }^{93}$ which has both pro- and anti-inflammatory effects, ${ }^{94}$ depending on the tissue that expresses the cytokine. Therefore, anti-inflammatory agents might also impair the recovery process.

Anticoagulants have been suggested for use in COVID-19 to mitigate the risk of venous and arterial thromboembolism. ${ }^{15,16,95}$ Anticoagulants such as heparin promote angiogenesis but dilate blood vessels, meaning that exercise-induced hypotension is a potential outcome. Exercise, particularly at higher intensities, is also known to promote angiogenesis and vasodilation, partly to regulate temperature. ${ }^{96}$ Therefore, caution with exercise prescription is required to mitigate the increased risk of bleeding while using anticoagulation agents in patients with enhanced bleeding risk and to prevent injury and further complications.

Table 1 Classes of pharmaceutical agents being trialled for COVID-19, intended action, potential side effects associated with their use, and considerations for exercise

\begin{tabular}{|c|c|c|c|}
\hline $\begin{array}{l}\text { Pharmaceutical } \\
\text { class }\end{array}$ & Intended action & Potential side effects/ interactions & Consideration for exercise \\
\hline Anticoagulants & $\begin{array}{l}\text { Suppression of synthesis/function of } \\
\text { various clotting factors to prevent the } \\
\text { formation of blood clots }\end{array}$ & $\begin{array}{l}\text { Hemorrhage } \\
\text { Thrombocytopenia } \\
\text { Hypersensitivity reactions } \\
\text { Adverse interactions with other drugs that } \\
\text { bind to plasma proteins or are } \\
\text { metabolized by the liver }\end{array}$ & $\begin{array}{l}\uparrow \text { Blood fluidity \& blood flow, } \\
\uparrow \text { oxygen delivery. } \\
\text { Excessive bleeding. } \\
\text { Exercise induced hypotension }\end{array}$ \\
\hline Antiviral agents & $\begin{array}{l}\text { Blocks viral entry to host cells } \\
\text { - Serine protease inhibitors } \\
\text { Blocks viral replication in host cells } \\
\text { Inhibits angiotensin-converting } \\
\text { enzyme } 2\end{array}$ & $\begin{array}{l}\text { Joint and/or muscle pain } \\
\text { Headaches, dizziness, nausea } \\
\text { Cough, nasal congestion, fever, body } \\
\text { aches, malaise, and, in severe cases, death }\end{array}$ & $\begin{array}{l}\text { J-shaped hypothesis for exercise dose and } \\
\text { infection risk. } \\
\downarrow \text { Proprioception due to neuropathy \& } \\
\downarrow \text { muscle control due to myopathy and } \\
\text { muscle weakness. }\end{array}$ \\
\hline Corticosteroids & $\begin{array}{l}\text { Regulates gene expression to } \\
\text { suppress inflammation and immune } \\
\text { responses }\end{array}$ & $\begin{array}{l}\text { Can } \uparrow \text { risk and severity of infections, } \\
\text { as well as masking infections } \\
\text { May cause elevated blood glucose levels, } \\
\text { fluid retention, or elevated blood pressure } \\
\text { Long-term use may suppress the immune } \\
\text { system } \\
\text { May } \uparrow \text { gastrointestinal symptoms } \\
\text { Can } \downarrow \text { bone density, cause osteoporosis, } \\
\text { and } \uparrow \text { risk of fractures } \\
\text { Affects metabolism fat deposition } \\
\text { Impaired ability to sleep } \\
\text { Mood changes ( }>30 \text { mg/day) } \\
\text { Eye problems } \\
\text { Atherosclerosis and aseptic necrosis (long- } \\
\text { term use and high doses) } \\
\text { Withdrawal can cause fatigue, joint pain, } \\
\text { muscle stiffness and tenderness, or fever }\end{array}$ & $\begin{array}{l}>2 \text { wk use } \downarrow \text { ability of the body to } \\
\text { respond to physical stress. } \\
\text { Muscle weakness in people who may } \\
\text { already be strength compromised. } \\
\text { Potential for impaired physiological } \\
\text { response to exercise due to adrenal } \\
\text { gland dysfunction. } \\
\text { Potential for impaired neural signaling, } \\
\text { muscle damage, and muscle weakness. }\end{array}$ \\
\hline $\begin{array}{l}\text { Nonsteroidal } \\
\text { anti-inflammatory }\end{array}$ & $\begin{array}{l}\text { Inhibits COX-1 or COX-2 enzymes, thus } \\
\text { stopping prostaglandin production } \\
\text { Blocks toll-like receptors involved in } \\
\text { cytokine production }\end{array}$ & $\begin{array}{l}\text { Gastrointestinal irritation, fluid retention, } \\
\text { and elevated blood pressure } \\
\uparrow \text { Risk heart attack and stroke, dizziness, } \\
\text { light-headedness, tiredness, headache, } \\
\text { ringing in the ears }\end{array}$ & $\begin{array}{l}\text { During prolonged exercise, they may } \\
\text { strain the kidneys and } \downarrow \text { the ability of the } \\
\text { muscle to recover. } \\
\uparrow / \text { Exacerbate risk of injury as it masks } \\
\text { musculoskeletal pain. } \\
\uparrow \text { Blood pressure response with exercise, } \\
\text { particularly with higher intensities. } \\
\downarrow \text { Capacity for skeletal muscle oxygen } \\
\text { transfer } \downarrow \text { energy availability. }\end{array}$ \\
\hline $\begin{array}{l}\text { Disease- } \\
\text { modifying } \\
\text { antirheumatoid } \\
\text { drugs }\end{array}$ & $\begin{array}{l}\text { Antimalarial } \\
\text { - Destruction of parasite }\end{array}$ & $\begin{array}{l}\text { May be immunosuppressive, myelosup- } \\
\text { pressive, cause cardiac toxicity, or severe } \\
\text { low blood glucose levels }\end{array}$ & $\begin{array}{l}\text { Myelosuppressive side effects could } \\
\text { impair exercise capacity. } \\
\text { Reliance on aerobic energy metabolism. } \\
\text { Additional thermoregulation required. }\end{array}$ \\
\hline
\end{tabular}

Notes: $\uparrow$ increased; $\downarrow$ reduced/decreased. Intended action and potential side effects information obtained from the Australian Medicines Handbook (https://amhonline.amh.net.au/auth). This table is a general review only and is not specific to individual drugs. For a more empiric or investigational use of individualized agents with antithrombotic properties in COVID-19, please see the review by Bikdeli et al. ${ }^{15}$ 
Antiviral agents previously used to treat influenza have been reported to be effective for treating COVID-19. ${ }^{97}$ When these have been used in combination with immune system pharmaceuticals (i.e., antimalarial and protease inhibitors), symptoms have been alleviated, along with reduced viral shedding and hospital stay. ${ }^{98}$ Recognized side effects of antiviral agents include fatigue, dizziness, and poor mental health. ${ }^{89,99-101}$ Antimalarial agents have some common side effects with antiviral drugs, including dizziness and mental health issues along with other exercise prescription considerations such as muscle weakness, ${ }^{102,103}$ cardiac arrhythmia, ${ }^{104}$ and heart failure. ${ }^{89}$ Protease inhibitors also have the potential to induce cardiac arrhythmia ${ }^{105,106}$ and reduce metabolic control. ${ }^{107,108}$ Therefore, the use of exercise as an adjuvant therapy might be appropriate given the positive effects of exercise on all of the potential adverse reactions to the pharmaceutical agents (i.e., enhanced mood/mental health, ${ }^{109,110}$ cardiovascular and metabolic health ${ }^{57,111}$ ), along with the strong potential of low- to moderate-intensity exercise to directly affect the coagulation process. However, the setting and mode for exercise delivery needs to be carefully selected, thus avoiding the potential consequences of exacerbating symptoms of dizziness and the potential for falling and further injury. ${ }^{112}$

\section{Conclusion}

The association of abnormal coagulation with severe pneumonia and death in people with COVID-19 1,35 has led to reports on thromboembolic complications. ${ }^{34}$ This seems to be more apparent in people who also have cardiometabolic health conditions. Particularly in people who have mild or moderate symptoms of COVID-19, and perhaps those with more severe COVID-19, low- to moderate-intensity exercise could be regarded as adjuvant therapy to assist with minimizing the potential adverse reactions of the infection and any treatment-related issues. Furthermore, low- to moderate-intensity exercise might be important to contribute to reducing the risk of developing more severe forms of COVID19 and further reducing the risk of coagulopathy that seems to be associated with mortality. Yet, enhanced social distancing (i.e., at least $2 \mathrm{~m}$ ) while practicing outdoor sport and exercise would be mandatory since airborne virus propagation is considerably higher during physical exercise. ${ }^{113}$

\section{Conflict of Interest}

None.

\section{References}

1 Huang C, Wang Y, Li X, et al. Clinical features of patients infected with 2019 novel coronavirus in Wuhan, China. Lancet 2020;395 (10223):497-506

2 Wen J, Aston J, Liu X, Ying T. Effects of misleading media coverage on public health crisis: a case of the 2019 novel coronavirus outbreak in China. Anatolia 2020;31:331-336

3 WHO. WHO Coronavirus Disease (COVID-19) Dashboard. Available at: https://covid19.who.int/. Accessed 22 May, 2020

4 UNCTAD. Coronavirus: can policymakers avert a trillion-dollar crisis? Available at: https://unctad.org/en/pages/newsdetails. aspx?OriginalVersionID=2300. Accessed April 30, 2020
5 Lippi G, Plebani M, Henry BM. Thrombocytopenia is associated with severe coronavirus disease 2019 (COVID-19) infections: a meta-analysis. Clin Chim Acta 2020;506:145-148

6 Liu Y, Yang Y, Zhang C, et al. Clinical and biochemical indexes from 2019-nCoV infected patients linked to viral loads and lung injury. Sci China Life Sci 2020;63(03):364-374

7 Peng YD, Meng K, Guan HQ et al. Clinical characteristics and outcomes of 112 cardiovascular disease patients infected by 2019-nCoV [in Chinese]. Zhonghua Xin Xue Guan Bing Za Zhi 2020;48(00):E004

8 Terpos E, Ntanasis-Stathopoulos I, Elalamy I, et al. Hematological findings and complications of COVID-19. Am J Hematol 2020;95 (07):834-847

9 Gao Y, Li T, Han M, et al. Diagnostic utility of clinical laboratory data determinations for patients with the severe COVID-19. J Med Virol 2020;92(07):791-796

10 Cannegieter SC, Klok FA. COVID-19 associated coagulopathy and thromboembolic disease: commentary on an interim expert guidance. Res Pract Thromb Haemost 2020;4(04):439-445

11 Pallister CJ, Watson MS. Haematology. 2nd ed. Banbury, UK: Scion Publishing; 2010

12 Lowe GD. Virchow's triad revisited: abnormal flow. Pathophysiol Haemost Thromb 2003;33(5-6):455-457

13 Henry BM, de Oliveira MHS, Benoit S, Plebani M, Lippi G. Hematologic, biochemical and immune biomarker abnormalities associated with severe illness and mortality in coronavirus disease 2019 (COVID-19): a meta-analysis. Clin Chem Lab Med 2020;58(07):1021-1028

14 Levi M, Thachil J, Iba T, Levy JH. Coagulation abnormalities and thrombosis in patients with COVID-19. Lancet Haematol 2020;7 (06): $\mathrm{e} 438-\mathrm{e} 440$

15 Bikdeli B, Madhavan MV, Gupta A, et al; Global COVID-19 Thrombosis Collaborative Group. Pharmacological agents targeting thromboinflammation in COVID-19: review and implications for future research. Thromb Haemost 2020 (e-pub ahead of print) . Doi: 10.1055/s-0040-1713152

16 Hashemi A, Madhavan MV, Bikdeli B. Pharmacotherapy for prevention and management of thrombosis in COVID-19. Semin Thromb Hemost 2020 (e-pub ahead of print) . Doi: 10.1055/s0040-1714273

17 Monroe DM, Hoffman M. What does it take to make the perfect clot? Arterioscler Thromb Vasc Biol 2006;26(01):41-48

18 Versteeg HH, Heemskerk JW, Levi M, Reitsma PH. New fundamentals in hemostasis. Physiol Rev 2013;93(01):327-358

19 Verhamme P, Hoylaerts MF. The pivotal role of the endothelium in haemostasis and thrombosis. Acta Clin Belg 2006;61(05): 213-219

20 Kleinegris MC, Ten Cate-Hoek AJ, Ten Cate H. Coagulation and the vessel wall in thrombosis and atherosclerosis. Pol Arch Med Wewn 2012;122(11):557-566

21 Siahkouhian M, Khodadadi D, Bolboli L. Diurnal variation of haemostatic response to exercise in young sedentary males. Biol Sport 2013;30(02):125-130

22 Page MJ, Pretorius E. A champion of host defense: a generic largescale cause for platelet dysfunction and depletion in infection. Semin Thromb Hemost 2020;46(03):302-319

23 Larsen JB, Pasalic L, Hvas AM. Platelets in coronavirus disease 2019. Semin Thromb Hemost 2020 (e-pub ahead of print). Doi: 10.1055/s-0040-1710006

24 Wang D, Hu B, Hu C, et al. Clinical characteristics of 138 hospitalized patients with 2019 novel coronavirus-infected pneumonia in Wuhan, China. JAMA 2020 (e-pub ahead of print) . Doi: $10.1001 /$ jama.2020.1585

25 Prchal JT. Hypoxia and thrombosis. Blood 2018;132(04):348-349

26 Gupta N, Zhao YY, Evans CE. The stimulation of thrombosis by hypoxia. Thromb Res 2019;181:77-83

27 Thachil J, Srivastava A. SARS-2 coronavirus-associated hemostatic lung abnormality in COVID-19: is it pulmonary thrombosis 
or pulmonary embolism? Semin Thromb Hemost 2020 (e-pub ahead of print) . Doi: 10.1055/s-0040-1712155

28 Kwaan HC. Coronavirus disease 2019: the role of the fibrinolytic system from transmission to organ injury and sequelae. Semin Thromb Hemost 2020 (e-pub ahead of print) . Doi: 10.1055/s0040-1709996

29 Chen T, Wu D, Chen H, et al. Clinical characteristics of 113 deceased patients with coronavirus disease 2019: retrospective study. BMJ 2020;368:m1091

30 Guan WJ, Ni ZY, Hu Y, et al; China Medical Treatment Expert Group for Covid-19. Clinical characteristics of coronavirus disease 2019 in China. N Engl J Med 2020;382(18):1708-1720

31 Grasselli G, Zangrillo A, Zanella A, et al; COVID-19 Lombardy ICU Network. Baseline characteristics and outcomes of 1591 patients infected with SARS-CoV-2 admitted to ICUs of the Lombardy Region, Italy. JAMA 2020;323(16):1574-1581

32 Dutheil F, Gordon BA, Naughton G, et al. Cardiovascular risk of adipokines: a review. J Int Med Res 2018;46(06):2082-2095

33 Gaertner F, Massberg S. Blood coagulation in immunothrombosis-at the frontline of intravascular immunity. Semin Immunol 2016;28(06):561-569

34 Lodigiani C, Iapichino G, Carenzo L, et al; Humanitas COVID-19 Task Force. Venous and arterial thromboembolic complications in COVID-19 patients admitted to an academic hospital in Milan, Italy. Thromb Res 2020;191:9-14

35 Tang N, Li D, Wang X, Sun Z. Abnormal coagulation parameters are associated with poor prognosis in patients with novel coronavirus pneumonia. J Thromb Haemost 2020;18(04):844-847

36 Zhou F, Yu T, Du R, et al. Clinical course and risk factors for mortality of adult inpatients with COVID-19 in Wuhan, China: a retrospective cohort study. Lancet 2020;395(10229):1054-1062

37 Prisco D, Paniccia R, Bandinelli B, et al. Evaluation of clotting and fibrinolytic activation after protracted physical exercise. Thromb Res 1998;89(02):73-78

38 Schobersberger W, Wirleitner B, Puschendorf B, et al. Influence of an ultramarathon race at moderate altitude on coagulation and fibrinolysis. Fibrinolysis 1995;10(01):37-42

39 Nguyen NT, Owings JT, Gosselin R, et al. Systemic coagulation and fibrinolysis after laparoscopic and open gastric bypass. Arch Surg 2001;136(08):909-916

40 Parker BA, Augeri AL, Capizzi JA, et al. Effect of marathon run and air travel on pre- and post-run soluble d-dimer, microparticle procoagulant activity, and p-selectin levels. Am J Cardiol 2012; 109(10):1521-1525

41 Wells PS, Anderson DR, Rodger M, et al. Evaluation of D-dimer in the diagnosis of suspected deep-vein thrombosis. N Engl J Med 2003;349(13):1227-1235

42 Koehler KS, Bottoni T. The effect of exercise on D-dimer levels. Mil Med 2014;179(02):225-230

43 Henke PK, Pannucci CJ. Venous thromboembolism risk factor assessment and prophylaxis. Phlebology 2010;25(05):219-223

44 Kelly J, Rudd A, Lewis RR, Hunt BJ. Plasma D-dimers in the diagnosis of venous thromboembolism. Arch Intern Med 2002; 162(07):747-756

45 Schulman S. Coronavirus disease 2019, prothrombotic factors, and venous thromboembolism. Semin Thromb Hemost 2020 (epub ahead of print) . Doi: 10.1055/s-0040-1710337

46 Lippi G, Favaloro EJ. D-dimer is associated with severity of coronavirus disease 2019: a pooled analysis. Thromb Haemost 2020;120(05):876-878

47 Haskell WL, Lee IM, Pate RR, et al; American College of Sports Medicine; American Heart Association. Physical activity and public health: updated recommendation for adults from the American College of Sports Medicine and the American Heart Association. Circulation 2007;116(09):1081-1093

48 Lippi G, Henry BM, Sanchis-Gomar F. Physical inactivity and cardiovascular disease at the time of coronavirus disease 2019 (COVID-19). Eur J Prev Cardiol 2020;27(09):906-908
49 FitbitStaffThe impact of coronavirus on global activity. Available at: https://blog.fitbit.com/covid-19-global-activity/. Accessed May 29, 2020

50 Evidation Health. COVID-19 Pulse Study. Available at: https:// evidation.com/news/covid-19-pulse-first-data-evidation/.Accessed May 28, 2020

51 Goldhaber SZ, Bounameaux H. Pulmonary embolism and deep vein thrombosis. Lancet 2012;379(9828):1835-1846

52 Hull CM, Harris JA. Cardiology Patient Page. Venous thromboembolism and marathon athletes. Circulation 2013;128(25):e469-e471

53 Gregson J, Kaptoge S, Bolton T, et al; Emerging Risk Factors Collaboration. Cardiovascular risk factors associated with venous thromboembolism. JAMA Cardiol 2019;4(02):163-173

54 Lippi G, Favaloro EJ, Sanchis-Gomar F. Sudden cardiac and noncardiac death in sports: epidemiology, causes, pathogenesis, and prevention. Semin Thromb Hemost 2018;44(08):780-786

55 Lippi G, Sanchis-Gomar F, Henry BM. Coronavirus disease 2019 (COVID-19): the portrait of a perfect storm. Ann Transl Med 2020;8(07):497

56 Garber CE, Blissmer B, Deschenes MR, et al; American College of Sports Medicine. American College of Sports Medicine position stand. Quantity and quality of exercise for developing and maintaining cardiorespiratory, musculoskeletal, and neuromotor fitness in apparently healthy adults: guidance for prescribing exercise. Med Sci Sports Exerc 2011;43(07):1334-1359

57 Chodzko-Zajko WJ, Proctor DN, Fiatarone Singh MA, et al; American College of Sports Medicine. American College of Sports Medicine position stand. Exercise and physical activity for older adults. Med Sci Sports Exerc 2009;41(07):1510-1530

58 Panagiotakos DB, Pitsavos C, Chrysohoou C, Kavouras S, Stefanadis C; ATTICA Study. The associations between leisure-time physical activity and inflammatory and coagulation markers related to cardiovascular disease: the ATTICA Study. Prev Med 2005;40(04):432-437

59 Pitsavos C, Panagiotakos DB, Chrysohoou C, Kavouras S, Stefanadis C. The associations between physical activity, inflammation, and coagulation markers, in people with metabolic syndrome: the ATTICA study. Eur J Cardiovasc Prev Rehabil 2005;12(02):151-158

60 Zbinden-Foncea H, Francaux M, Deldicque L, Hawley JA. Does high cardiorespiratory fitness confer some protection against pro-inflammatory responses after infection by SARS-CoV-2? Obesity (Silver Spring) 2020(Apr):23

61 Chen P, Mao L, Nassis GP, Harmer P, Ainsworth BE, Li F. Coronavirus disease (COVID-19): the need to maintain regular physical activity while taking precautions. J Sport Health Sci 2020;9(02): 103-104

62 Szymanski LM, Pate RR. Fibrinolytic responses to moderate intensity exercise. Comparison of physically active and inactive men. Arterioscler Thromb 1994;14(11):1746-1750

63 Thrall G, Lane D, Carroll D, Lip GYH. A systematic review of the effects of acute psychological stress and physical activity on haemorheology, coagulation, fibrinolysis and platelet reactivity: implications for the pathogenesis of acute coronary syndromes. Thromb Res 2007;120(06):819-847

64 el-Sayed MS. Effects of exercise on blood coagulation, fibrinolysis and platelet aggregation. Sports Med 1996;22(05):282-298

65 Ferguson EW, Bernier LL, Banta GR, Yu-Yahiro J, Schoomaker EB. Effects of exercise and conditioning on clotting and fibrinolytic activity in men. J Appl Physiol (1985) 1987;62(04):1416-1421

66 Karampour S, Gaeini AA. Response of coagulation and anticoagulant factors of elite athletes following acute resistance and high-intensity interval training. J Sports Med Phys Fitness 2018;58(1-2):120-126

67 Kupchak BR, Creighton BC, Aristizabal JC, et al. Beneficial effects of habitual resistance exercise training on coagulation and fibrinolytic responses. Thromb Res 2013;131(06):e227-e234

68 Eriksson-Berg M, Egberg N, Eksborg S, Schenck-Gustafsson K. Retained fibrinolytic response and no coagulation activation 
after acute physical exercise in middle-aged women with previous myocardial infarction. Thromb Res 2002;105(06):481-486

69 Gram AS, Petersen M, Quist JS, Rosenkilde M, Stallknecht B, Bladbjerg EM. Effects of 6 months of active commuting and leisure-time exercise on fibrin turnover in sedentary individuals with overweight and obesity: a randomised controlled trial. J Obes 2018;2018:7140754

70 Braschi A. Acute exercise-induced changes in hemostatic and fibrinolytic properties: analogies, similarities, and differences between normotensive subjects and patients with essential hypertension. Platelets 2019;30(06):675-689

71 Posthuma JJ, van der Meijden PE, Ten Cate H, Spronk HM. Shortand long-term exercise induced alterations in haemostasis: a review of the literature. Blood Rev 2015;29(03):171-178

72 Weiss C, Welsch B, Albert M, et al. Coagulation and thrombomodulin in response to exercise of different type and duration. Med Sci Sports Exerc 1998;30(08):1205-1210

73 Lippi G, Salvagno GL, Tarperi C, et al. Prothrombotic state induced by middle-distance endurance exercise in middleaged athletes. Semin Thromb Hemost 2018;44(08):747-755

74 el-Sayed MS. Exercise intensity-related responses of fibrinolytic activity and vasopressin in man. Med Sci Sports Exerc 1990;22 (04):494-500

75 Menzel K, Hilberg T. Blood coagulation and fibrinolysis in healthy, untrained subjects: effects of different exercise intensities controlled by individual anaerobic threshold. Eur J Appl Physiol 2011;111(02):253-260

76 Röcker L, Möckel M, Westpfahl KP, Gunga HC. Influence of maximal ergometric exercise on endothelin concentrations in relation to molecular markers of the hemostatic system. Thromb Haemost 1996;75(04):612-616

77 Gunga HC, Kirsch K, Beneke R, et al. Markers of coagulation, fibrinolysis and angiogenesis after strenuous short-term exercise (Wingate-test) in male subjects of varying fitness levels. Int J Sports Med 2002;23(07):495-499

78 Hilberg T, Prasa D, Stürzebecher J, Gläser D, Schneider K, Gabriel HH. Blood coagulation and fibrinolysis after extreme short-term exercise. Thromb Res 2003;109(5-6):271-277

79 Zadow EK, Kitic CM, Wu SSX, Fell JW, Adams MJ. Time of day and short-duration high-intensity exercise influences on coagulation and fibrinolysis. Eur J Sport Sci 2018;18(03):367-375

80 Cuzzolin L, Lussignoli S, Crivellente F, et al. Influence of an acute exercise on neutrophil and platelet adhesion, nitric oxide plasma metabolites in inactive and active subjects. Int J Sports Med 2000;21(04):289-293

81 Kvernmo HD, Osterud B. The effect of physical conditioning suggests adaptation in procoagulant and fibrinolytic potential. Thromb Res 1997;87(06):559-569

82 Szymanski LM, Pate RR, Durstine JL. Effects of maximal exercise and venous occlusion on fibrinolytic activity in physically active and inactive men. J Appl Physiol (1985) 1994;77(05):2305-2310

83 Gonzales F, Mañas M, Seiquer I, et al. Blood platelet function in healthy individuals of different ages. Effects of exercise and exercise conditioning. J Sports Med Phys Fitness 1996;36(02): 112-116

84 Womack CJ, Ivey FM, Gardner AW, Macko RF. Fibrinolytic response to acute exercise in patients with peripheral arterial disease. Med Sci Sports Exerc 2001;33(02):214-219

85 DeSouza CA, Dengel DR, Rogers MA, Cox K, Macko RF. Fibrinolytic responses to acute physical activity in older hypertensive men. J Appl Physiol (1985) 1997;82(06):1765-1770

86 Morris PJ, Packianathan CI, Van Blerk CJ, Finer N. Moderate exercise and fibrinolytic potential in obese sedentary men with metabolic syndrome. Obes Res 2003;11(11):1333-1338

87 Ivey FM, Womack CJ, Kulaputana O, Dobrovolny CL, Wiley LA, Macko RF. A single bout of walking exercise enhances endogenous fibrinolysis in stroke patients. Med Sci Sports Exerc 2003; 35(02):193-198
88 Shetty R, Ghosh A, Honavar SG, Khamar P, Sethu S. Therapeutic opportunities to manage COVID-19/SARS-CoV-2 infection: present and future. Indian J Ophthalmol 2020;68(05):693-702

89 Abd El-Aziz TM, Stockand JD. Recent progress and challenges in drug development against COVID-19 coronavirus (SARS-CoV-2) - an update on the status. Infect Genet Evol 2020;83:104327

90 Hendren NS, Drazner MH, Bozkurt B, Cooper LT Jr. Description and proposed management of the acute COVID-19 cardiovascular syndrome. Circulation 2020;141(23):1903-1914

91 Bhimraj A, Morgan RL, Shumaker AH, et al. Infectious Diseases Society of America guidelines on the treatment and management of patients with COVID-19. Clin Infect Dis 2020;2000: ciaa478

92 Franchini M, Del Fante C, Klersy C, et al. Challenges in the production of convalescent hyperimmune plasma in the age of COVID-19. Semin Thromb Hemost 2020 (e-pub ahead of print) . Doi: $10.1055 / \mathrm{s}-0040-1713433$

93 Sebba A. Tocilizumab: the first interleukin-6-receptor inhibitor. Am J Health Syst Pharm 2008;65(15):1413-1418

94 Scheller J, Chalaris A, Schmidt-Arras D, Rose-John S. The pro- and anti-inflammatory properties of the cytokine interleukin-6. Biochim Biophys Acta 2011;1813(05):878-888

95 Tang N, Bai H, Chen X, Gong J, Li D, Sun Z. Anticoagulant treatment is associated with decreased mortality in severe coronavirus disease 2019 patients with coagulopathy. J Thromb Haemost 2020;18(05):1094-1099

96 Żebrowska A, Jastrzębski D, Sadowska-Krępa E, Sikora M, Di Giulio C. Comparison of the effectiveness of high-intensity interval training in hypoxia and normoxia in healthy male volunteers: a pilot study. BioMed Res Int 2019; 2019:7315714

97 Jahangir M, Muheem A, Rizvi M. Coronavirus (COVID-19): history, current knowledge and pipeline medications. Int J Pharm 2020;4(01):2581-3080

98 Hung IF-N, Lung K-C, Tso EY-K, et al. Triple combination of interferon beta- $1 \mathrm{~b}$, lopinavir-ritonavir, and ribavirin in the treatment of patients admitted to hospital with COVID-19: an open-label, randomised, phase 2 trial. Lancet 2020;395 (10238):1695-1704

99 Monto AS. The role of antivirals in the control of influenza. Vaccine 2003;21(16):1796-1800

100 Chutaputti A. Adverse effects and other safety aspects of the hepatitis C antivirals. J Gastroenterol Hepatol 2000;15(Suppl): E156-E163

101 Yu WC, Hui DSC, Chan-Yeung M. Antiviral agents and corticosteroids in the treatment of severe acute respiratory syndrome (SARS). Thorax 2004;59(08):643-645

102 Veinot JP, Mai KT, Zarychanski R. Chloroquine related cardiac toxicity. J Rheumatol 1998;25(06):1221-1225

103 Marrelli MT, Brotto M. The effect of malaria and anti-malarial drugs on skeletal and cardiac muscles. Malar J 2016;15(01): 524

104 Verny C, de Gennes C, Sébastien P, et al. Heart conduction disorders in long-term treatment with chloroquine. Two new cases [in French]. Presse Med 1992;21(17):800-804

105 Friis-Møller N, Reiss P, Sabin CA, et al; DAD Study Group. Class of antiretroviral drugs and the risk of myocardial infarction. N Engl J Med 2007;356(17):1723-1735

106 Mondy KE, Gottdiener J, Overton ET, et al; SUN Study Investigators. High prevalence of echocardiographic abnormalities among HIV-infected persons in the era of highly active antiretroviral therapy. Clin Infect Dis 2011;52(03):378-386

107 Carr A, Samaras K, Chisholm DJ, Cooper DA. Pathogenesis of HIV1-protease inhibitor-associated peripheral lipodystrophy, hyperlipidaemia, and insulin resistance. Lancet 1998;351 (9119):1881-1883

108 Hui DY. Effects of HIV protease inhibitor therapy on lipid metabolism. Prog Lipid Res 2003;42(02):81-92 
109 Polman R, Kaiseler M, Borkoles E. Effect of a single bout of exercise on the mood of pregnant women. J Sports Med Phys Fitness 2007;47(01):103-111

110 Yeung RR. The acute effects of exercise on mood state. J Psychosom Res 1996;40(02):123-141

111 Pollock MLGG, Butcher JD, et al. American College of Sports Medicine position stand. The recommended quantity and quality of exercise for developing and maintaining cardiorespiratory and muscular fitness, and flexibility in healthy adults. Med Sci Sports Exerc 1998;30(06):975-991

112 Lippi G, Henry BM, Bovo C, Sanchis-Gomar F. Health risks and potential remedies during prolonged lockdowns for coronavirus disease 2019 (COVID-19). Diagnosis (Berl) 2020;7(02):85-90

113 Halabchi F, Ahmadinejad Z, Selk-Ghaffari M. COVID-19 epidemic: exercise or not to exercise; that is the question!. Asian J Sports Med 2020 (e-pub ahead of print) . Doi: 10.5812/asjsm.102630 